\title{
HOW DO STUDENTS OF CHEMISTRY TEACHING PROGNOSE THE IMPACT OF GRAPHICAL PART OF DIDACTICAL TESTS? SELECTED ASPECTS OF VISUALIZATION IN SCIENCE EDUCATION
}

\author{
Martin Bílek, Antonín Slabý \\ University of Hradec Králové, Czech Republic
}

\begin{abstract}
For the first pilot research in the scope of the project Learning from graphical presentation in science education (GAČR 406/02/1165) there has been chosen investigation of the role of non-verbal elements of didactic tests. For solving of this task there was used comparison of the results of pupils of basic school performing two variants of the test with the same content and different form of formulation and arrangement of items (verbal form and form comprising visual information (pictures and graphs). In the contribution there are described starting points of the project, the interpretation obtained, experimental data from the point of view of typology of picture material as a part of didactic tests and mainly the point of view and the attitude of the students of chemistry teaching to the influence of graphical elements to the fruitfulness of students in didactic tests.
\end{abstract}

Key words: learning from the picture material, primary chemistry education, didactical tests and effectiveness of non-verbal part of didactical tests, chemistry teacher education.

\section{Introduction}

Visual perception, elaboration of visual information and subsequent creation of adequate conception of pupils and students appears to be substantial part of education of science subjects. Graphical presentation represents in the era of coming information and communication technologies into process of education substantial part of educational materials in all stages of school system. Group of researchers at the University of Hradec Králové started to work at the research project which aims to analyse various ways of elaborating non verbal (graphical, picture) information during the education of science subjects (Bílek, 2002a). Partial aims of the project focus on description of the function of picture material in educational texts and devices with main concentration to their electronic form i.e. to educational possibility of computer graphics, animation and simulation of science phenomena and their principles and to the description and interpretation of the models and elaboration of visual information of learners. The results should tribute to optimization of the creation and increasing pedagogical effectiveness of educational texts based on multimedia, educational CD-DVD and Internet technology. On the other hand the results should tribute to improving of professional part of chemistry teachers education - improving of subject methodology in area of non-verbal part of educational texts. This is the rationale of the research part of the article.

\section{Theoretical Base I - Verbal and Non Verbal Aspects of Human Education}

Sumfleth et al. (2002) similarly as Pavlíková (1999) quote in their works Mayer's Cognitive Theory of Multimedia Learning, which comprises five starting-points for meaningful education supported by multimedia devices:

○ Selection of words,

- Selection of images,

- Organisation of words,

- Organisation of images,

$\circ$ Ways of integration of words and images.

At the same time there is necessary to distinguish three important aspects of effective elaborating of information by learning people: 
- Presented verbal information has to be connected with verbal information anticipated by learning people (previous information possessing verbal base),

- Presented visual information has to be connected with visual information anticipated by learning people (previous information possessing picture base),

- Time and space connection presented by visual and verbal information is crucial for learners.

Time and space connection between verbal and visual information is crucial in creating mental models required by learning people for decoding teaching material substantially easier (Sumfleth, Huellen \& Telgenbüscher, 2002).

Mareš (1995) gives some differences in the role played by verbal and visual part of human learning from the point of view of pupil's development. In pre school age verbal and non-verbal communication is more connected and the child who still cannot read devotes great proportion of its attention to visual materials. In school age verbal and nonverbal parts start to disconnect and printed or written text prevails. Mareš (1995) also claims that pupils are taught to read systematically. Less attention is devoted to the process of comprehending the text by reading it. Way of learning from visual material and obtaining new information from it is usually not taught at school at all. It is supposed some self-evident plasticity or the fact that the picture possesses self-explanatory attribute.

Very wide and vague notion plasticity but often does not possess the role of sufficiently suitable description of concrete graphical image in the process of education. Let us mention one of known the Mayer's classification of picture material according to its prevailed function classification given in Pavlíková (1999). Picture material may have the following dominated functions:

○ Decoration,

- Representation,

- Transformation,

- Organisation,

- Interpretation.

Platteaux et al. (2002) claims in his empiric study on combination of visual and text material in e-course of embryology for students of medicine that the most effective function is the level transformation (visual information helps to decode information given in the text) and the level interpretation (visual information supports imagination of concrete content in the relation to the text). On the other hand the worst effectiveness was recorded for pure decorations as it does not semantic relation to towards the text. Other authors ascribe great importance to the decorative function also and mention its contribution to the evolvement of aesthetic experience and removal of difficult text anxiety etc. (Mareš, 1995).

Weidenmann (1994) in his studies on mastering knowledge by means of picture material establishes several principle problems. First of them is ability to distinguish realistic and logic pictures. Realistic images such as colour photography, detailed drawing, realistic picture or schematic draft describe to certain degree a real closeness to the described object. The main purpose of logical images or schemes is to create adequate conception on connection among some qualitative and quantitative aspects of certain object. Reception of the real world by means of realistic pictures is according to Weidenmann called first order understanding. It corresponds everyday life, outer experience, superficial interpretation etc. This aspect at logical images may but deceive. Then it is necessary to reach second order understanding and decoding implicit connections and relations among qualitative and quantitative aspects of image. Every imager possess according to this theory primary explicit depicting code and primary implicit directing code. Issing developed further this theory by setting apart the specific aspects of image analogy into so-called semiotic classification of categories of pictures (Telgenbüscher, 1998):

- Picture analogies,

- Realistic images (realistic picture and photography), 
○ Logical images (tables, graphs, diagrams, charts).

From the point of view of science teaching problems Telgenbüscher (1998) introduces important classification in picture distinction according to visual level to:

○ Sensory (macroscopic) level,

- Atomic and molecular (sub microscopic) level,

- Symbolic level.

\section{Theoretical Base II - Cybernetic Aspects of the Learning from the Picture Material}

From the point of view of education technology and educational cybernetics there is possible to make use of findings about psycho-structured model of the process of learning introduced for example in Frank (1996) or the theory of so called double coding mentioned in Paivio (1986). Research work in the didactic of chemistry which appears to be the most contiguous science learning branch for us was performed by Johnstone (1997). Johnstone similarly as Frank describes in his psycho-structural model of pupil certain building elements (model of operations) crucial for human reception and learning. He distinguishes: Stimulation - Perception Filter (Accommodator) - Working Space in the Memory (Operation Memory) Long Term Memory (Storage) influencing accommodator. Johnstone in contrast to Franks cybernetic pedagogy is not engaged with strictly quantitative expressing of the content of the parts of psycho-structural model (in bits) but he divides parts of information content of teaching material into basic and at already well mastered operations ("pieces"), which must be performed in pupils operation memory. Method is sometimes called as "chunking" - dividing. Johnstone in his experiments with high school population in the area of chemical equilibrium discovered empirically the limit of possible operation, which can be performed in operation memory of learning people and called it capacity of operation memory. If learners reach the limit, their ability to solve more complicated tasks dropped substantially. This can be illustrated by easy experiment with keeping row of letters in mind. In time limit 10 seconds as is described in (Bílek, 2002b):

- AVPSNQ (6 letters are memorised without problems),

- MPLSVCAEOKNZ (12 letters causes substantial problems to memorize),

- MOCVLKNESZAP (12 letters of the previous task divided into four words makes memorizing possible again).

Example derived from the chemistry area demonstrates differences in memorizing structural and functional chemical formula (for example $\mathrm{CH}_{3}-\mathrm{CH}_{2}-\mathrm{COO}-\mathrm{CH}_{3}$ ).

This proves the application of so called "supering" i.e. creating of supersigns. Realization of making super signs is possible by two ways by creating of classes and complexes. In the scope of our project there are prepared experiments with graphical material and searching similar dependences.

Theory of double coding tries to assign the same meaning to both verbal and non-verbal processes. Information is according to this theory processed in memory in the two separate coding systems having close mutual relations. A lot of empiric results prove that double coded information is memorized substantially better. Well known is also information about certain changes in relation of both these above mentioned coding systems in dependence of the age of learners (Mareš, 1995).

\section{Theoretical Base III - Several Examples of the Influence of Picture Material to Learning in Science Subjects}

In spite of the fact, that learning from picture material is so far very little investigated problem of scientific research, it was possible to analyse in the first literature search part of our above mentioned project several important studies having this set and proving positive influence of the picture material applied under certain specifically defined conditions. Sumfleth 
et al. (2002) presented results of Mayer and Galini on the influence of combination of verbal and visual information. Research was performed with for groups of respondents. First group had for its disposal text about technical device without pictures. The second might use images having description of various components; the third group had pictures with description of components and explanation of their function, and the fourth the organically arranged sequence of pictures, with description of components and explanation of their function (,steps and parts"). Out of these four groups the fourth achieved he best results and substantially better results in education than other three groups. Similar research having similar results was later arranged by Sumfleth, Hüllen and Telgenbüscher. This presents a combination of text and picture material of the chemistry for the $12^{\text {th }}$ year of study at high school. The concrete teaching material concerned addition reaction of bromine to double binding between carbon atoms. Other research about learning from picture material in the subject matter of chemistry, which we analysed, can be found in Pavlíková (1999), Gnoyke (1995) or Telgenbüscher (1998).

\section{Methodology of Research}

First pilot research of our above mentioned project (Bílek, 2002a) concerned investigation of the role of non-verbal elements of didactic tests (Bílek, Slabý, Konírová \& Hruška, 2003). There were compared the results of two groups of pupils of basic school solving two variants of the test having the same content as to subject matter but different form of submitting of items (verbal form for the first group and the form comprising images or graphs (non verbal elements)). There was proved positive but not distinct influence of graphical elements in the most of test items to the success by solving test tasks (see Figures 1 3). Relatively weak pupils (as to study results) achieved the biggest difference.

The second part of the pilot project was devoted to investigation of the influence of the attitude of pupils to learning to study results in verbal and picture test by using of "Index of Learning Styles (ILS) - part ,verbal versus visual“ learning attitude (Solomon, Felder, 2001). In this part there were supposed much better results by those pupils who we able to make use of harmony between the form of the test and their attitude toward learning (visual attitude - picture test and verbal attitude - verbal test). This assumption was but not proved. Pupils with verbal attitude achieved much better results by learning solving the picture variant of the test (Bílek, Slabý, Konířová \& Hruška, 2003).

The important role in teaching from the picture material by analogy to the verbal learning is based by previous knowledge. Series of research works is consequently focused on comparative study of reception of pictures by so called experts (having certain level of knowledge of presented subject matter) and so called non-specialists (who have minimum knowledge in the area learned). This fact plays by our view important role in educational process from the teachers as expert in the selection of adequate presentation of the subject matter.

We concentrate to this aspect in connection with some investigation in the area of didactic tests of chemistry at basic school in the third part of our project (mentioned in this paper). We examined prognosis of students of chemistry teaching concerning the influence of picture elements of didactic test to success of students in the tests.

\section{Results of Research}

Important role in teaching from the picture material is based by previous knowledge. Our research topic focuses on comparative study of reception of pictures by so called experts (having certain level of knowledge of presented subject matter) and so called non-specialists (who have minimum knowledge in the area learned). We examined prognosis of students of 
chemistry teaching to the influence of picture elements of didactic test to the success of students in the tests.

The students were made to formulate their opinion about the differences in results in individual items of the test: will the average result be substantially better in the test item of the variant with pictures scale 4 or better in the test item of the variant with pictures scale 3 or the same for both variants scale 2 or better at picture variant scale 1 or substantially better at picture variant scale 0 (expert assessment at the scale $4-0$; value 2 represents insignificant influence of the form of item of the didactic test). Results of group of future chemistry teachers are presented in Table 1.

\section{Nr. 18}

Jak obecně postupujeme při ředění kyselin (především kyseliny sírové):

a) přiléváme vodu do kyseliny,

b) přiléváme po tyčince kyselinu do vody,

c) přiléváme po tyčince vodu do kyseliny,

d) přiléváme kyselinu do vody.

$10,1 \%$

Nr. 18

$30,4 \%$

Jak obecně postupujeme při ředění kyselin (především kyseliny sírové):

a)

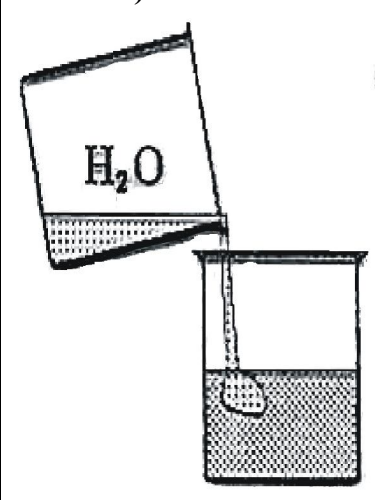

$\mathrm{H}_{2} \mathrm{SO}_{4}$ b)

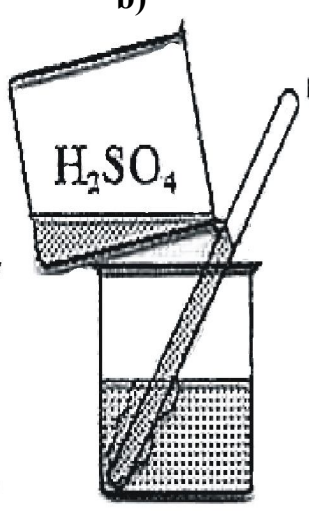

$\mathrm{H}_{2} \mathrm{O}$ c)

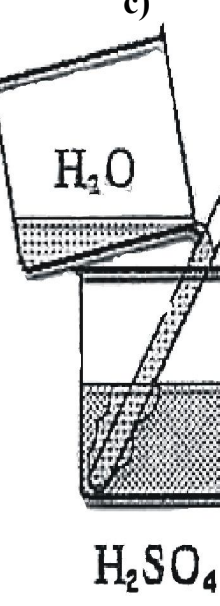

d)

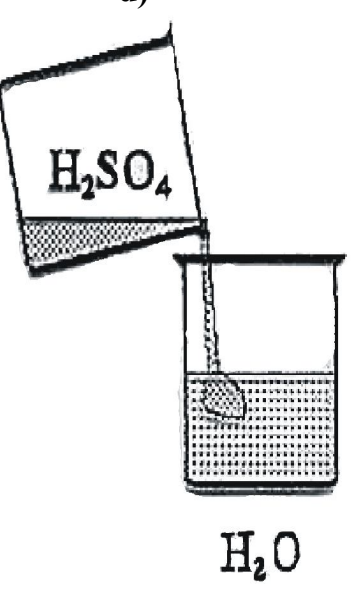

Figure 1 The scan of two variants the $18^{\text {th }}$ test item (estimation 2,06 out of 4 given by number in circle and results of tests $(10,1 \%$ and $30,4 \%)$ given by other two numbers shows underestimation of prognosis from future teachers). 
Nr. 1

Jaká směs vznikne smícháním uvedených látek?

Přiřad' k číslům písmena tak, aby vznikla pravdivá tvrzení.
a) kuchyňská sůl, saze
b) saze, voda
c) ethanol, voda
d) kuchyňská sůl, voda

1. směs stejnorodá:

2. směs různorodá:

Nr. 1

Jaká směs vznikne smícháním uvedených látek?

Přiřad' k číslům písmena tak, aby vznikla pravdivá tvrzení.

a)

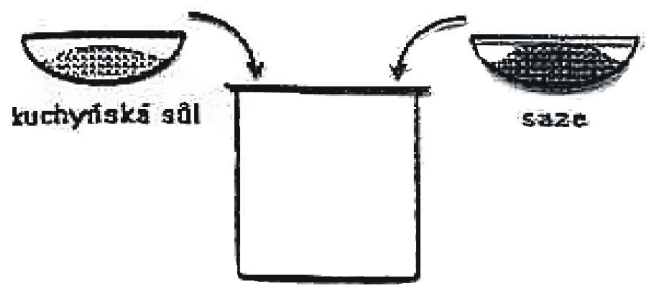

c)

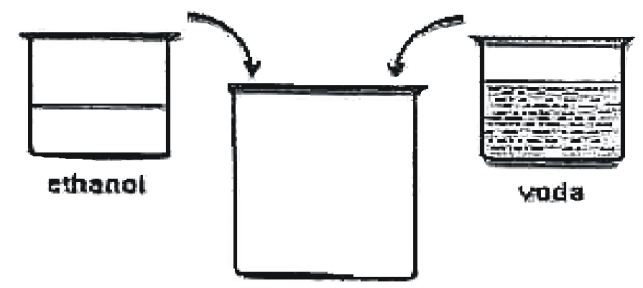

b)

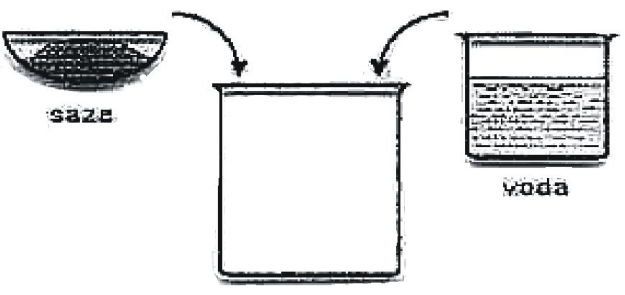

d)

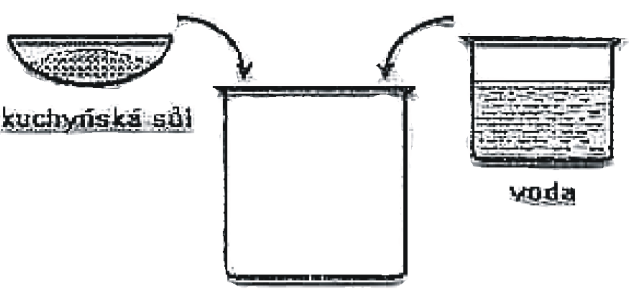

1. směs stejnorodá:

2. směs různorodá:

Figure 2. The scan of both variants the $1^{\text {st }}$ item. Verbal form of item with result $36.9 \%$ and graphical form of item with $19,9 \%$ show bad influence of graphical elements. Prognosis 2.33 shows low estimation of future teachers. 
Nr. 10

Následující větu si nejprve celou pozorně přečti a potom v ní doplň chybějící údaje.

Atom se skládá $\mathrm{z}$

ve kterém se nachází kladně nabité kde obíhají záporně nabité

a elektricky neutrální a $\mathrm{z}$ $60,6 \%$ $82,6 \%$

\section{Nr. 10}

Následující obrázek si nejprve celý pozorně prohlédni a potom v něm doplň chybějící údaje.

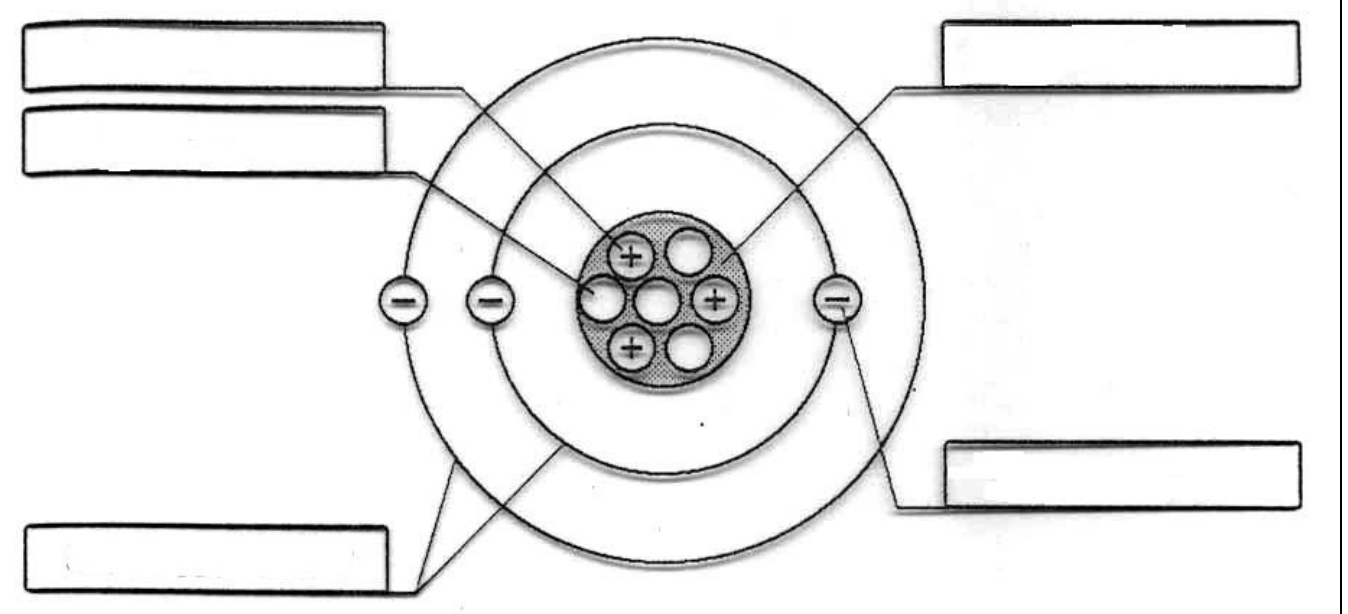

Figure 3. The scan of both variants of the $10^{\text {th }}$ item. Numbers $60,6 \%$ (result of verbal form) and 82,6\% (result of graphical form) show good influence of graphical elements to pupil's results and number 3,06 shows good prognosis from future teachers.

Estimation of future chemistry teachers about impact of graphical part of test-items and results of pupils

\begin{tabular}{|c|c|c|c|}
\hline $\begin{array}{c}\text { Nr. of } \\
\text { Item in } \\
\text { Test }\end{array}$ & $\begin{array}{c}\text { Average of Pointing } \\
\text { Scale Evaluation } \\
\text { from Future } \\
\text { Teachers }\end{array}$ & $\begin{array}{c}\text { Percentage of } \\
\text { Successfully Responds of } \\
\text { Pupils in Verbal Form of } \\
\text { Test }\end{array}$ & $\begin{array}{c}\text { Percentage of } \\
\text { Successfully Responds of } \\
\text { Pupils in Graphical } \\
\text { Form of Test }\end{array}$ \\
\hline 1 & 2.33 & 36.9 & 9.9 \\
\hline 2 & 2.61 & 34.3 & 39.9 \\
\hline 3 & 2.78 & 24.3 & 24.9 \\
\hline 4 & 2.39 & 57.8 & 71.2 \\
\hline 5 & 3 & 48.7 & 46.7 \\
\hline 6 & 1.17 & 87.9 & 51.8 \\
\hline
\end{tabular}




\begin{tabular}{|c|c|c|c|}
\hline $\begin{array}{c}\text { Nr. of } \\
\text { Item in } \\
\text { Test }\end{array}$ & $\begin{array}{c}\text { Average of Pointing } \\
\text { Scale Evaluation } \\
\text { from Future } \\
\text { Teachers }\end{array}$ & $\begin{array}{c}\text { Percentage of } \\
\text { Successfully Responds of } \\
\text { Pupils in Verbal Form of } \\
\text { Test }\end{array}$ & $\begin{array}{c}\text { Percentage of } \\
\text { Successfully Responds of } \\
\text { Pupils in Graphical } \\
\text { Form of Test }\end{array}$ \\
\hline 7 & 2.22 & 66.7 & 61.0 \\
\hline 8 & 3 & 79.0 & 78.2 \\
\hline 9 & 1.5 & 26.5 & 22.3 \\
\hline 10 & 3.06 & 60.6 & 82.6 \\
\hline 11 & 3.17 & 51.2 & 60.6 \\
\hline 12 & 2.78 & 39.7 & 45.9 \\
\hline 13 & 2.39 & 41.4 & 47.8 \\
\hline 14 & 1.89 & 86.9 & 94.9 \\
\hline 15 & 1.38 & 43.9 & 69.2 \\
\hline 16 & 2.67 & 65.4 & 62.7 \\
\hline 17 & 2.33 & 35.9 & 28.0 \\
\hline 18 & 2.06 & 10.1 & 30.4 \\
\hline 19 & 3.72 & 62.6 & 51.3 \\
\hline 20 & 2.56 & 34.1 & 43.3 \\
\hline
\end{tabular}

Out of the examination performed there follow some interesting conclusions, which may serve as starting point for further research in mentioned area. Let us mention some important findings:

1) Students suppose at most test items of the test (13 items out of 20 items) positive influence of the picture elements to test results of pupils of basic school.

2) Students estimated only by 9 items of the test (out of 20 items) correctly positive, weak or negative influence of picture elements (with 5 percent tolerance).

3) Students substantially overestimated positive influence of the symbolic expressing of situation in comparison with verbal description. (For example: "symbolic versus verbal definition of amount of substance" - substantially better results were achieved by students; "record of proton number as part of the symbol of the element" - it was achieved only a tiny difference on behalf of the picture variant i.e. symbolic expression though the subsequent discussion held with students proved knowledge of Piaget theory of teaching stages (here was proved only isolated knowledge without application ability of this matter etc.).

4) Students substantially underestimated auxiliary information obtained from graphs in comparison with tables (properties of halogens).

5) Students substantially overestimated the influence of the drawing of chemical apparatus to solving of the task (task concerning selection of distillation apparatus, task including either drawing or description of the position of the hydrometer in the cylinder by finding of the density of given liquid).

\section{Conclusions}

The main aim of the mentioned project there was analysis of the ways of pupils/students learning by means of visual devices in the following contexts: from static to dynamic images, the consequences of excessive and insufficient stress of plasticity, ways of verifying of the effectiveness of learning from picture materials, contribution to classification of the learning styles using picture material in comparison with results of known research in the area of learning styles from text materials, influence of the way of presentation of material.

In the presented part of research activity were monitored results of chemistry teacher's education in the area of impact of nonverbal elements of educational materials. It is evident 
that student's knowledge about elaboration of graphical information by pupils is very rudimentary, fragmented and consequently little useful.

Partial results obtained cannot be overestimated so far due to limited number of respondents and short experience with methodology of used research. Consequently further research will address larger number of respondents, will comprise rearrangement of research methods and used devices and transition to analysis of electronic forms of educational materials making use of findings of the research of classical forms of presentation of teaching materials.

\section{Acknowledgment} (GAČR)

The contribution is supported by the project 406/02/1165 of the Czech Grant Agency

\section{References}

Bílek, M. (2002a). Learning from Graphical Presentation in Science Education. Proposal of Research Project, Czech Grant Agency (GAČR 406/02/1165), Hradec Králové: PdF UHK.

Sumfleth, E., Huellen, R., Telgenbüscher, L. (2002). Optimierung von Bildern für den Chemieunterricht. ChemKon, 3, $122-129$.

Pavlíková, A. (2002). About Didactical Starting-Points of Educational Environment Creation in Conditions of Distance Learning (in Slovak). In: eLearn - Žilina 2002 (pp. 89 - 94). Žilina: EDIS Publisher of Žilina University.

Mareš, J. (1995). Learning from Picture Material (in Czech). Pedagogika, XLV, 318 - 327.

Platteaux, H. et al. (2002). Pedagogical evaluation of a Web-based training in embryology: A study of image-text combinations. In: 4th ICNEE - Proceedings (p. 2.1/45), Lugano: net4net.

Weidenmann, B. (Hrsg.) (1994). Wissenserwerb mit Bildern. Instruktionale Bilder in Printmedien, Film/Video und Computerprogrammen. Bern - Göttingen - Toronto - Seattle: Verlag Hans Huber.

Telgenbüscher, L. (1998). Zur Visualisierung von chemischen Konzepten - Untersuchung von Lernumgebungen und Lernparametern für effektives Lernen mit Bildern. (Dissertation), Essen: Universität. SAIS, 1996

Frank, H. (1996). Bildungskybernetik/Klerigkibernetiko. Bratislava und Nitra: Esprima und

Paivio, A. (1986). Mental Representations: a Dual Coding Approach. New York: Oxford University Press.

Johnstone, A. H. (1997). J. Chem. Educ., 74, $262-268$.

Bílek, M. (2002b): Cybernetics Aspects of Visualisation in Science Education (in Czech). In: E. Poláková (ed.), Die Kybernetik in die Theorie und Praxis (pp. 123 - 128), Nitra: UKF.

Pavlíková, A. (1999). The Analysis of Picture Material in Chemistry Text-books by View of Learning (Diploma Thesis in Slovak), Trnava: PdF TU.

Gnoyke, A. (1995): Das Lernen mit Bildern in der Chemie - Aktion und Interaktion von Wahrnehmen und Denken. (Dissertation), Essen: Universität.

Bílek, M., Slabý, A, Konířová, V., Hruška, L. (2003). Investigation of the Influence of Nonverbal Parts of Didactical Tests in Primary Chemistry Education. In: M. Bílek (ed.), Visualisation in Science and Technical Education (pp. 49 - 54), Edition: Didactics of Science and Technical Subjects, Volume 2, Hradec Králové: Gaudeamus.

Mašek, J. (1995): Some Aspects of Teaching of Visual and Audio-Visual Literacy (in Czech). In: MEDACTA 95 (pp. 39 - 44), Nitra: PdF UKF.

Turčáni, M., Fojtík, R., Polák, J. (2001). Distance Teaching and e-Learning in Informatics (In Slovak). Technológia vzdelávania, 10/IX., 2 - 7.

Slabý, A., Bílek, M. (2001). Promotion of Geometrical Imagination by Mathematical Modelling and Visualization in Technical Teacher Training. In: A. Melezinek (Hrsg.), Lust am Lehren, Lust am Lernen (pp. 416 - 419), Leuchturm-Schriftenreihe Ingenieurpädagogik, Band 45, Alsbach: LeuchturmVerlag.

Solomon, B. A., Felder, R. M.: Index of Learning Styles (ILS Questionnaire) [online] htpp://www2.ncsu.edu/unity/lockers/users/felder/public/ILSdir/ILS-b.htm (cit. 2001-03-06) 


\section{Santrauka \\ KAIP CHEMIJĄ STUDIJUOJANTYS STUDENTAI PROGNOZUOJA DIDAKTINIŲ \\ TESTU VAIZDINĖS DALIES POVEIKİ. RINKTINIAI GAMTAMOKSLINIO UGDYMO VIZUALIZAVIMO ASPEKTAI}

\section{Martin Bílek, Antonín Slabý}

Šis tyrimas grindžiamas anksčiau atliktu tyrimu, kuris buvo vykdytas kaip projekto dalis. Buvo vykdytas projektas „Mokymasis taikant vaizdines perezentacijas gamtamokslinio ugdymo procese“ (GAČR 406/02/1165). Šiam tyrimui pasirinktas objektas - neverbalinių didaktinių testu elementu vaidmuo. Buvo palyginti pagrindinès mokyklos moksleivių rezultatai pagal du testo variantus. Testų turinys buvo vienodas, o forma (klausimų, užduočių formuluotės ir išdėstymas) skirtinga /verbalinè dalis ir dalis, sudaryta iš vizualios informacijos - paveikslų ir diagramų/. Šiame straipsnyje aprašomi pirmieji rezultatai, kurie gauti pradejjus projekto vykdymą. Analizuojami ịvairūs aspektai, tokie kaip moksleivių požiūris ị testus, kurie sudaryti skirtinga forma, ypač daug dẻmesio skiriant vizualizavimui, o taip pat moksleivių nuostatos i tokius testus.

Raktiniai žodžiai: mokymasis naudojant vaizdines priemones, didaktiniai testai, testo efektyvumas, chemijos mokytojų ugdymas/rengimas.

\section{Ph. D. Martin Bílek}

Head of Section for Chemistry Didactics,

Department of Chemistry, Pedagogical Faculty,

University of Hradec Králové, V.Nejedleho Str. 573,

CZ-500 03 Hradec Kralove, Czech Republic

E-mail: martin.bilek@uhk.cz

\section{Ph. D. Antonín Slabý}

Department of Informatics, Faculty of Informatics and Management

University of Hradec Králové, V.Nejedleho Str. 573,

CZ-500 03 Hradec Kralove, Czech Republic

E-mail: antonin.slaby@uhk.cz 